\title{
PENGARUH PEMBERIAN TEPUNG INDIGOFERA DALAM KONSENTRAT TERHADAP PERFORMA PRODUKSI DOMBA EKOR GEMUK
}

\section{THE EFFECT OF INDIGOFERA FLOUR IN CONCENTRATE ON FAT TAIL SHEEP PRODUCTION PERFORMANCE}

\author{
N T Tambakª, E Dihansih'1, dan D Kardaya
}

${ }_{1}^{1}$ Programstudi Peternakan Fakultas Pertanian Universitas Djuanda Bogor, Jl. Tol Ciawi No. 1, Kotak Pos 35 Ciawi, Bogor 16720.

aKorespondensi: Novitri Tarigan Tambak, E-mail: novitritarigan23.nt@gmail.com

(Diterima oleh Dewan Redaksi: 29 Oktober 2021)

(Dipublikasikan oleh Dewan Redaksi: 31 oktober 2021)

\begin{abstract}
This research was carried out from May 26 to July 26 2018, at Mitra Tani Farm, Tegal Waru Village, RT 04 RW 05, Ciampea District, West Bogor. This study aims to find out information about the effect of indigofera flour in concentrate on the production performance of fat-tailed sheep during fattening. The sheep used in this study were 12 heads $(11 \mathrm{~kg})$ with a total of one year old female. The experimental design used was a completely randomized design with 4 treatments and 3 replications for each treatment. The variables observed in this study were feed consumption, body weight gain and feed conversion. The data obtained will be analyzed by means of variance (ANOVA) and using the Tukey further test. The results obtained from each week of rearing showed that feed consumption, weight gain and feed conversion were significantly different at 6 to 8 weeks. very significant $(P>0.01)$ and feed conversion was significant ( $\mathrm{P}>0.05$ ). Fat Tailed Sheep can be given up to $30 \%$ indigofera flour for 60 days of rearing so that body weight gain is better and more efficient in feed.
\end{abstract}

Keywords: performance, fat tail sheep, indigofera.

\begin{abstract}
ABSTRAK
Penelitian ini telah dilaksanakan pada tanggal 26 Mei sampai 26 Juli 2018, di Peternakan Mitra Tani Desa Tegal Waru RT 04 RW 05, Kecamatan Ciampea, Bogor Barat. Penelitian ini bertujuan untuk mengetahui informasi tentang pengaruh pemberian tepung indigofera dalam konsentrat terhadap performa produksi domba ekor gemuk selama penggemukan. Domba yang digunakan dalam penelitian ini adalah 12 ekor $(11 \mathrm{~kg})$ dengan keseluruhan betina dengan umur satu tahun. Rancangan percobaan yang digunakan adalah Rancangan Acak Lengkap dengan 4 perlakuan dan masing-masing perlakuan 3 ulangan. Peubah yang diamati pada penelitian ini adalah konsumsi pakan, pertambahan bobot badan dan konversi pakan. Data yang diperoleh akan dianalisis dengan sidik ragam (ANOVA) dan menggunakan uji lanjut Tukey. Hasil yang diperoleh dilihat dari setiap minggu pemeliharaan menunjukkan bahwa konsumsi pakan, pertambahan bobot dan dan konversi pakan berbeda nyata pada minggu ke 6 sampai ke 8. Namun secara keseluruhan performa domba ekor gemuk selama 2 bulan pemeliharaan menunjukkan konsumsi pakan tidak nyata sedangkan pertambahan bobot badan domba sangat nyata $(\mathrm{P}>0,01)$ dan konversi pakan nyata $(\mathrm{P}>0,05)$. Domba Ekor Gemuk dapat diberikan tepung indigofera sampai $30 \%$ selama 60 hari pemeliharaan sehingga pertambahan bobot badan lebih baik serta lebih efisien terhadap pakan.
\end{abstract}

Kata Kunci: performa, domba ekor gemuk, indigofera.

NT Tambak, E Dihansih, D Kardaya. 2021. Pengaruh Pemberian Tepung Indigofera Dalam Konsentrat Terhadap Performa Produksi Domba Ekor Gemuk. Jurnal Peternakan Nusantara 7(2): 73-78. 


\section{PENDAHULUAN}

Domba merupakan salah satu sumber protein hewani yang ikut berperan dalam penyediaan daging dalam negeri. Data dari Direktorat Jendral Peternakan (DitJenNak 2016) populasi ternak domba pada tahun 2016 sekitar 18,06 juta dibandingkan populasinya pada tahun 2012 sekitar 13,42 juta, terjadi kenaikan 34,61\%. Oleh karena kebutuhan masyarakat yang terus meningkat diperlukan juga peningkatan terhadap manajemen pemeliharaan domba. Performa produksi ternak harus diperbaiki, salah satunya adalah pertambahan bobot badan, konversi serta konsumsi. Secara umum domba lokal di Jawa Timur dan wilayah Timur Indonesia didominasi oleh domba ekor gemuk. Karakteristik yang khas pada domba DEG adalah ekor yang besar, panjang dan lebar. Bagian pangkal ekor membesar berisi suatu timbunan lemak sedangkan bagian ujung ekor mengecil tidak berlemak. Salah satu bahan pakan yang kemungkinan dapat digunakan sebagai pakan alternatif sumber serat dan protein yang murah adalah Indigofera sp. Sebagaimana menurut Abdullah dan Suharlina 2010 kandungan protein tepung indigofera antara 23,66 sampai $31,1 \%$. Penelitian ini bertujuan mengkaji pengaruh pemberian tepung daun indigofera terhadap performa produksi domba ekor gemuk baik konsumsi, pertambahan bobot badan dan konversi pakan.

\section{MATERI DAN METODE}

\section{Materi}

Penelitian ini dilaksanakan pada tanggal 26 mei 2018 sampai dengan 26 juli 2018 . Lokasi yang dipilih sebagai tempat pelaksanaan penelitian yaitu dipeternakan domba CV. Mitra Tani Farm, Jl. Baru Manunggal 51 No. 39, Desa Tegal Waru RT 04 RW 05 Ciampea Bogor, Jawa Barat. Wilayah ini memiliki ketinggian $400 \mathrm{~m}$ diatas permukaan laut.

\section{Bahan}

Ternak domba yang digunakan dalam penelitian ini berjumlah 12 ekor, dengan ratarata bobot badan $11 \mathrm{~kg}$. Ternak yang digunakan seluruhnya adalah domba ekor gemuk dengan jenis kelamin betina. Domba bakalan yang digunakan berasal dari Kediri, Jawa Timur. Domba yang digunakan berumur satu tahun. Pakan yang diberikan adalah konsentrat, hijauan dan tepung indigofera. Konsentrat yang diberikan merupakan konsentrat komersial. Bahan-bahan yang digunakan dalam penyusunan konsentrat ini adalah dedi padi, kulit singkong dan ampas tahu. Hijauan yang diberikan adalah rumput lapang yang diberikan secara ad libitum (tersedia terus).

\begin{abstract}
Alat
Peralatan yang digunakan pada penelitian ini adalah kandang individu yang berbentuk panggung dan bersekat-sekat dengan ukuran 90x40x60 $\mathrm{cm}$. Kandang individu tersebut sudah dilengkapi dengan tempat pakan dan tempat minum. Peralatan lain yang digunakan adalah timbangan dengan kapasitas 5 $\mathrm{kg}$ untuk menimbang pakan dan sisa pakan, timbangan besar dengan kapasitas $50 \mathrm{~kg}$ untuk menimbang bobot hidup domba, ban bekas sebagai penahan domba saat ditimbang. Peralatan lain yang digunakan adalah ember, karung, sapu lidi, sekop, troli, lampu dan alat tulis.
\end{abstract}

\section{Perlakuan}

Perlakuan penelitan adalah sebagai berikut: R0 $=$ Konsentrat $100 \%, \mathrm{R} 1=$ Konsentrat $90 \%+$ $10 \%$ tepung indigofera, $\mathrm{R} 2=$ Konsentrat $80 \%+$ $20 \%$ tepung indigofera, R3 $=$ Konsentrat $70 \%+$ $30 \%$ tepung indigofera

\section{Rancangan Percobaan}

Metode penelitian menggunakan metode eksperimen dengan rancangan percobaan Rancangan Acak Lengkap (RAL) dengan 4 perlakuan masing-masing diulang 3 kali sehingga total domba yang digunakan 12 ekor domba.

\section{Peubah yang Diamati}

a. Konsumsi pakan : Pakan yang diberikanSisa pakan

b. PBBH (g/hari) : Bobot badan akhir (g) bobot badan awal (g)

c. Konversi pakan : konsumsi pakan (g/ekor/hari)/ PBB (g/ekor/hari) 


\section{Analisis Data}

Data yang diperoleh dianalisis ragam (ANOVA) yang sebelumnya telah dilakukan uji asumsi. Data yang dilakukan analisis ragam yaitu konsumsi pakan, pertambahan bobot badan dan konversi pakan. Data hasil analisis yang berpengaruh nyata dilanjutkan uji banding Tukey untuk mengetahui perbedaan diantara perlakuan dan uji Polinominal Orthogonal untuk mengetahui taraf optimum yang diberikan (Steel dan Torrie 1993).

\section{Prosedur Pelaksanaan}

Setelah daun indigofera dikumpulkan ataupun dipanen, lalu dikeringkan sampai benar-benar kering. Pengeringan daun indigofera dibawah sinar matahari $29-30^{\circ}$. Lalu daun yang sudah kering tersebut, digiling sampai menjadi tepung. Tepung indigofera yang dipergunakan pada saat penelitian diperoleh dari Cianjur. Kandang disemprot dengan desinfektan serta seluruh peralatan yang akan digunakan dicuci bersih sebelum pemeliharaan.

Penelitian akan dilakukan selama 8 minggu ( 2 bulan) yang dimulai tanggal 26 Mei sampai 21 Juli 2018. Pemberian pakan dilakukan dua kali sehari yaitu pagi hari (pukul 07.00 WIB) dan sore hari (pukul 16.30). Sebelum domba diberi pakan, pakan ditimbang dan catat terlebih dahulu sisa pakan yang diberikan sebelumnya. Pemberian konsentrat dan indigofera diberikan dua kali sehari, sedangkan untuk pemberian hijauan dan air dilakuakn ad libitum. Penimbangan bobot badan dilakukan seminggu sekali. Konversi pakan dihitung secara matematika diakhir penelitian. Selama domba digemukkan dilakukan perawatan kandang, tempat pakan dan minum dipastikan bersih setiap hari. Kotoran dibawah kandang dibersihkan setiap hari.

\section{HASIL DAN PEMBAHASAN}

\section{Keadaan Umum Lokasi dan Kondisi Ternak}

Kandang yang digunakan untuk penelitian ini adalah kandang individu berbentuk panggung dan bersekat-sekat dengan ukuran 90x40x60 cm, sedangkan kandang koloni digunakan untuk domba penggemukan lainnya yang ada di Mitra Tani Farm. Kandang ini membujur dari arah timur ke barat sehingga cahaya matahari di pagi hari dapat masuk menerangi bangunan kandang, karena sinar ultraviolet yang ada pada cahaya matahari pagi dapat membunuh bibit penyakit dan selain itu juga dapat mengeringkan kandang. Jumlah ternak domba yang dipelihara di peternakan Mitra Tani pada saat penelitian dilaksanakan yaitu bulan Mei adalah 400 ekor domba sedangkan dibulan Juni sebanyak 500 ekor domba. Ternak yang digunakan adalah bakalan yang sehat dan normal (tidak cacat). Ternak yang digunakan berasal dari Kediri, Jawa Timur.

\section{Konsumsi Pakan}

Hasil penelitian pada Tabel 1 menunjukkan konsumsi pada minggu 1, 2, 3, 4 dan 5 konsumsi pakan tidak ada perbedaan nyata. Menurut Nur'adhadinia (2011), bahwa adaptasi terhadap lingkungan dan pakan berlangsung selama empat minggu. Tingkat konsumsi ternak dipengaruhi oleh beberapa faktor yaitu faktor ternak, faktor makanan yang diberikan dan faktor lingkungan (suhu dan kelembaban). Suhu udara yang tinggi maka konsumsi pakan akan menurun karena konsumsi air minum yang tinggi berakibat penurunan konsumsi energi (Siregar, 1984). Suhu rata-rata selama penelitian pada siang hari $34,2{ }^{\circ} \mathrm{C}$ dan sore hari cukup $30,3{ }^{\circ} \mathrm{C}$ tinggi dengan kelembabapan pada pagi hari 83,8\%. Menurut Yousef (1985), kondisi lingkungan nyaman (thermoneutral zone) untuk domba berkisar $24-26^{\circ} \mathrm{C}$ dengan kelembaban dibawah $75 \%$.

Tabel 1 Rataan Konsumsi Pakan Domba Ekor Gemuk Selama Penelitian

\begin{tabular}{ccccc}
\hline Min & \multicolumn{4}{c}{ Perlakuan } \\
\cline { 2 - 5 } ggu & R0 & R1 & R2 & R3 \\
\hline 1 & $1242,8 \pm$ & $1471,4 \pm$ & $1454,8 \pm$ & $1388,1 \pm$ \\
& 247,5 & 14,3 & 25,1 & 41,2
\end{tabular}




\begin{tabular}{ccccc}
2 & $1116,8 \pm$ & $1423,9 \pm$ & $1384,8 \pm$ & $1323,0 \pm$ \\
& 242,9 & 50,9 & 51,9 & 164,4 \\
3 & $1460,3 \pm$ & $1483,3 \pm$ & $1473,1 \pm$ & $1436,3 \pm$ \\
& 5,9 & 28,9 & 13,4 & 47,7 \\
4 & $1486,0 \pm$ & $1491,7 \pm$ & $1476,1 \pm$ & $1479,0 \pm$ \\
& 24,2 & 14,4 & 9,5 & 21,5 \\
5 & $1456,7 \pm$ & $1489,3 \pm$ & $1475,7 \pm$ & $1484,0 \pm$ \\
& 51,3 & 10,1 & 24,8 & 6,6 \\
6 & $1425,3 \pm$ & $1495,0 \pm$ & $1494,3 \pm$ & $1455,3 \pm$ \\
& $17,5 \mathrm{C}$ & $5 \mathrm{~A}$ & $6 \mathrm{~A}$ & $5 \mathrm{~B}$ \\
7 & $1451,3 \pm$ & $1489,3 \pm$ & $1486,7 \pm$ & $1461,7 \pm$ \\
& $9,9 \mathrm{C}$ & $10,1 \mathrm{~A}$ & $15,3 \mathrm{AB}$ & $2,9 \mathrm{BC}$ \\
8 & $1457,7 \pm$ & $1492,7 \pm$ & $1493,3 \pm$ & $1470,0 \pm$ \\
& $2,1 \mathrm{~B}$ & $6,4 \mathrm{~A}$ & $11,5 \mathrm{~A}$ & $5 \mathrm{~B}$ \\
\hline
\end{tabular}

Ket : R0 $=$ Konsentrat 100\%, R1=Konsentrat $90 \%+10 \%$ Tepung Indigofera, R2= Konsentrat $80 \%+20 \%$ Tepung Indigofera, R3= Konsentrat $70 \%+30 \%$ Tepung Indigofera. Superkrip yang berbeda pada baris yang sama menunjukkan perbedaan sangat nyata $(A, B, C ; P<0,01)$, berbeda nyata(a,b,c; $\mathrm{P}<0,05)$

minggu ke 6 sampai ke 8 pada tabel menunjukkan sangat berbeda nyata $(\mathrm{P}<0,01)$. Perbedaan tingkat konsumsi ini disebabkan karena domba yang sudah beradaptasi dengan pemberian tepung indigofera. Domba ekor gemuk yang diberi tepung indigofera memberikan nilai konsumsi yang lebih tinggi dibandingkan kontrol. Perbedaan konsumsi bahan kering disebabkan perbedaan kandungan nutrient (Negesse et al,2001), status fisiologis, jenis kelamin ternak, serta bahan penyusun ransum. Konsumsi bahan kering domba diberi tepung indigofera lebih tinggi diduga karena perbedaan total kandungan nutrient terutama proteinnya seiring pernyataan Negesse at al, (2001) yang menyebutkan bahwa perbedaan konsumsi bahan kering disebabkan oleh kandungan nutrient yaitu protein. Protein dalam pakan ternak sangat penting untuk pembentukan jaringan tubuh (Maryani et al,2015).

\section{Pertambahan Bobot Badan}

Tabel 2. Rataan Pertambahan Bobot Badan Domba Domba Ekor Gemuk Selama Penelitian

\begin{tabular}{|c|c|c|c|c|}
\hline \multirow{2}{*}{$\begin{array}{l}\text { Min } \\
\text { ggu }\end{array}$} & \multicolumn{4}{|c|}{ Perlakuan } \\
\hline & R0 & R1 & R2 & R3 \\
\hline \multirow[t]{2}{*}{1} & $400,0 \pm 2$ & $566,7 \pm 2$ & $466,7 \pm 2$ & $600,0 \pm 1$ \\
\hline & 64,6 & 88,7 & 30,9 & 00,0 \\
\hline \multirow[t]{2}{*}{2} & $566,7 \pm 1$ & $700,0 \pm 2$ & $683,3 \pm 1$ & $566,7 \pm 5$ \\
\hline & 15,5 & 00,0 & 75,6 & 7,7 \\
\hline \multirow[t]{2}{*}{3} & $500,0 \pm 1$ & $833,3 \pm 3$ & $950,0 \pm 1$ & $716,7 \pm 1$ \\
\hline & 00,0 & 05,5 & 32,3 & 60,7 \\
\hline \multirow[t]{2}{*}{4} & $500,0 \pm 1$ & $800,0 \pm 2$ & $633,3 \pm 1$ & $816,7 \pm 1$ \\
\hline & 00,0 & 64,6 & 15,5 & 89,3 \\
\hline \multirow[t]{2}{*}{5} & $533,3 \pm 1$ & $633,3 \pm 5$ & $700,0 \pm 2$ & $700,0 \pm 2$ \\
\hline & 52,8 & 7,7 & 00,0 & 00,0 \\
\hline \multirow[t]{2}{*}{6} & $433,3 \pm 1$ & $850,0 \pm 1$ & $666,7 \pm 5$ & $700,0 \pm 1$ \\
\hline & $15,5 \mathrm{~B}$ & $32,3 \mathrm{~A}$ & 7,7AB & $00,0 \mathrm{AB}$ \\
\hline \multirow[t]{2}{*}{7} & $440,0 \pm 5$ & $720,0 \pm 2$ & $800,0 \pm 1$ & $766,7 \pm 1$ \\
\hline & $2,9 b$ & $43,3 a$ & $00,0 \mathrm{a}$ & $52,8 \mathrm{a}$ \\
\hline \multirow[t]{2}{*}{8} & $450,0 \pm 5$ & $650,0 \pm 5$ & $733,3 \pm 1$ & $533,3 \pm 5$ \\
\hline & $0,0 \mathrm{~b}$ & $0,0 \mathrm{ab}$ & $52,8 \mathrm{a}$ & 7,7ab \\
\hline
\end{tabular}

Ket : R0 $=$ Konsentrat $100 \%, \mathrm{R} 1=$ Konsentrat $90 \%+10 \%$ Tepung Indigofera, R2= Konsentrat $80 \%+20 \%$ Tepung Indigofera, R3= Konsentrat $70 \%+30 \%$ Tepung Indigofera. Superkrip yang berbeda pada baris yang sama menunjukkan perbedaan sangat nyata $(A, B, C$; $<<0,01)$, berbeda nyata(a,b,c; $\mathrm{P}<0,05)$

Hasil penelitian dari tabel 2 menunjukkan bahwa pertambahan bobot badan domba ekor gemuk pada minggu pertama sampai minggu ke 5 tidak berbeda nyata.

Hasnudi dan Wahyuni (2005) menunjukkan bahwa PBB yang tidak berbeda nyata dapat disebabkan ternak domba mengkonsumsi pakan yang jumlahnya tidak berbeda nyata. Pertumbuhan bobot badan mingguan domba sangat berbeda nyata pada minggu ke 6 sedangkan untuk minggu 7 dan ke 8 berbeda nyata. Pertambahan bobot badan harian paling tinggi adalah pada perlakuan R1 sebesar $102.7 \mathrm{~g} / \mathrm{ekor} /$ hari. Pertambahan bobot badan harian perlakuan R2dan R3 tidak berbeda jauh, namun lebih baik dari R0. Pertambahan bobot badan juga berkolerasi positif dengan konsumsi pakan. Perbedaan konsumsi pakan tersebut yang menyebabkan perbedaan PBB pada ternak. Konsumsi bahan kering yang lebih tinggi pada perlakuan pemberian tepung indigofera, berpengaruh terhadap PBB yang lebih besar dibandingkan perlakuan tanpa pemberian tepung indigofera.

\section{Konversi Pakan}

Tabel 3. Rataan Konversi Pakan Domba Ekor Gemuk Selama Penelitian 


\begin{tabular}{cclll}
\hline Ming & \multicolumn{4}{c}{ Perlakuan } \\
\cline { 2 - 5 } gu & \multicolumn{1}{c}{ R0 } & \multicolumn{1}{c}{ R1 } & \multicolumn{1}{c}{ R2 } & \multicolumn{1}{c}{ R3 } \\
\hline 1 & $4,3 \pm 2,8$ & $3,0 \pm 1,2$ & $4,0 \pm 2,7$ & $2,3 \pm 0,4$ \\
2 & $2,1 \pm 0,8$ & $2,1 \pm 0,6$ & $2,1 \pm 0,6$ & $2,3 \pm 0,1$ \\
3 & $3,0 \pm 0,6$ & $1,9 \pm 0,9$ & $1,5 \pm 0,2$ & $2,0 \pm 0,5$ \\
4 & $3,0 \pm 0,6$ & $2,0 \pm 0,6$ & $2,4 \pm 0,5$ & $1,8 \pm 0,5$ \\
5 & $2,8 \pm 0,8$ & $2,3 \pm 0,2$ & $2,2 \pm 0,7$ & $2,2 \pm 0,7$ \\
6 & $3,9 \pm 0,8$ & $1,7 \pm 0,3$ & $2,2 \pm 0,2$ & $2,1 \pm 0,3$ \\
& A & B & B & B \\
7 & $3,3 \pm 0,4$ & $2,2 \pm 0,6$ & $1,9 \pm 0,2$ & \\
& $\mathrm{a}$ & ab & b & $2,0 \pm 0,4 \mathrm{~b}$ \\
8 & $3,3 \pm 0,4$ & $2,3 \pm 0,2$ & $2,1 \pm 0,4$ & $2,8 \pm 0,3$ \\
& A & B & B & AB \\
\hline
\end{tabular}

Ket : $\mathrm{R} 0=$ Konsentrat $100 \%, \quad \mathrm{R} 1=$ Konsentrat $90 \%+10 \%$ Tepung Indigofera, R2= Konsentrat $80 \%+20 \%$ Tepung Indigofera, R3= Konsentrat $70 \%+30 \%$ Tepung Indigofera. Superkrip yang berbeda pada baris yang sama menunjukkan perbedaan sangat nyata $(A, B, C ; P<0,01)$, berbeda nyata(a,b,c; $\mathrm{P}<0,05)$.

Efisiensi penggunaan ransum dapat ditentukan dengan cara membandingkan jumlah ransum yang dikonsumsi dengan pertambahan bobot badan yang dihasilkan selama kurun waktu pemeliharaan tertentu (feed conversion) Metkono et al (2011). Rataan konversi pakan pada penelitian ini tercantum dalam Tabel 3. Dapat dilihat pada tabel bahwa pada minggu ke 1 sampai dengan minggu ke 5 menunjukkan bahwa perlakuan tidak berpengaruh nyata terhadap konversi pakan domba. Konversi pakan yang tidak berbeda nyata sejalan dengan konsumsi bahan kering dan pertambahan bobot badan.

Hasil penelitian pada minggu ke 6 dan ke 8 menunjukkan bahwa perbedaan sangat nyata $(\mathrm{P}<0,01)$. Sedangkan pada minggu ke 7 terdapat perbedaan yang nyata $(\mathrm{P}<0,05)$ konversi pakannya. Menurut standar NRC (2006) yang menyatakan bahwa konversi pakan domba sekitar 5,74. Konversi pakan domba selama pemeliharaan dengan dengan menggunakan R0 sebesar 3,2. Untuk nilai konversi pakan yang paling bagus yaitu dengan menggunakan $\mathrm{R} 1$ dengan nilai 2,1.

Performa domba ekor gemuk selama penelitian dari Tabel 4 menunjukkan bahwa konsumsi pakan tidak berbeda nyata, Pertambahan bobot badan sangat berbeda nyata sedangkan konversi pakannya berbeda nyata. Konsumsi tertinggi ada pada R1 yaitu 35509,9 gram sedangkan nilai konsumsi terendah yaitu pada pakan control sebesar 33290,8 gram.
Pertambahan bobot badan tertinggi terjadi pada R1 : 17260 gram. Lalu kemudian menurun dari R2: 16900 gram, R3: 16200 gram dan R1: 11470 gram.

\section{Performa Domba Ekor Gemuk Selama Penelitian}

Tabel 4. Performa Domba Ekor Gemuk Selama Penelitian (60 hari)

\begin{tabular}{ccccc}
\hline Peubah & R0 & R1 & R2 & R3 \\
\hline & 3329 & 35509, & 35216, & 34492, \\
Konsumsi & 0,8 & 9 & 5 & 1 \\
& 1147 & 17260 & 16900 & 16200 \\
PBB & 0 & $\mathrm{~A}$ & $\mathrm{~A}$ & $\mathrm{~A}$ \\
Konversi & $2,9 \mathrm{a}$ & $2 \mathrm{~b}$ & $2,1 \mathrm{~b}$ & $2,1 \mathrm{~b}$ \\
\hline
\end{tabular}

Superkrip yang berbeda pada baris yang sama menunjukkan perbedaan sangat nyata $(\mathrm{A}, \mathrm{B}, \mathrm{C}$ ; $\mathrm{P}<0,01)$, berbeda nyata(a,b,c; $\mathrm{P}<0,05)$.

Angka konversi yang semakin kecil menunjukkan bahwa pakan yang digunakan semakin efisien, begitu juga sebaliknya Sudrajat et al (2014). Perlakuan R1 memperlihatkan hasil konversi paling rendah mencapai 2 selama penelitian. (Table 4). Hasil menunjukkan bahwa yang tertinggi ada pada R0 dengan 2,9.

\section{KESIMPULAN DAN IMPLIKASI}

\section{Kesimpulan}

Pemberian tepung indigofera dengan pemberian sampai $30 \%$ dapat meningkatkan pertambahan bobot badan dan konversi pakan domba ekor gemuk yang dipelihara selama 60 hari.

\section{DAFTAR PUSTAKA}

Abdullah L, Suharlina. 2010. Herbage Yield and Quality of Two Vegetative Parts ofAccession. J Animal Feed Science and Technology 136: 312-322.and Species on Chemical omposition and In Vitro Digestibility of Five Indigofera.

Direktorat Jendral Bina Produksi Peternakan. 2006. Statistik Peternakan. Direktorat Jendral Bina Produksi Peternakan, Departemen Pertanian, Jakarta.

Hasnudi \& T. H. Wahyuni. 2005. Pengaruh Penggunaan Hasil Sampingan Industri 
Kelapa Sawit dan Limbah Pertanian

Terhadap Performans dan Bobot

Potong Domba Sei Putih. J. AGRIPET. 1 (1): 1-17.

Maryani A, Kardaya D, dan Dihansih E. 2015.

Performa Produksi Kelinci Lokal yang

Diberikan Pakan Tambahan Tepung

Daun Sirsak. Jurnal Peternakan

Nusantara 1(1):17-24. [accessed Oct 06 2018].

Metkono OAF, Kardaya D, Sudrajat D. 1011. Performa Domba Lokal Yang Diberi

Ransum Rumput Lapang dan Ampas

Tahu Yang Dipelihara Secara

Tradisional. Jurnal Pertanian ISSN

2087-4936 Volume 2 Nomor 2 ,

Oktober 2011.

National Research Council. 2006. Nutrient

Requirements of Small Ruminants

(Sheep, Goats, Cervids, and New

World Camelids). National Academic

Press. Washington, D.C. Pertanian

Bogor.

Negesse T, Rodehutscord M, Pfeffer E. 2001.

The effect of dietary crude protein lev on intake, growth, proteim retention, and utilization of growing male Saanen kids. Small umin. Res. 39:243-351.

Nur'adhadinia. 2011. Performa Pertumbuhan Domba Lokal Yang Diberi Pakan Level
Ampas Kurma Berbeda. Penelitian IPB, Bogor

Siregar, S.B. 1994. Ransum Ternak

Ruminansia. Penebar Swadaya. Jakarta

Steel RGD, Torrie JH. 1993. Prinsip dan

Prosedur Statistika. Terjemahan: M.

Syah. Jakarta (ID): Gramedia.

Yousef MK. 1985. Stress Physiology in Livestock: Basic Principle. Ed ke-1. Florida (US) 